\title{
ANALISIS INTERAKSI SOSIAL DALAM FILM G 30 S/PKI KARYA ARIFIN C NOER
}

\author{
Desi Pitriani $^{1}$, Sumiharti $^{2}$, Sujoko $^{3}$ \\ Program Studi Pendidikan Bahasa dan Sastra Indonesia, \\ Fakultas Keguruan dan Ilmu Pendidikan, Universitas Batanghari, \\ Jambi \\ pitrianidesi3@gmail.com \\ harti.sumi@yahoo.com \\ sujoko1987@yahoo.com
}

\begin{abstract}
The purpose of this research is to analyze literary work in a form of film. This research is also aimed at describing the aspects of social interaction in the film $G 30 \mathrm{~S} / \mathrm{PKI}$ by Arifin $\mathrm{C}$ Noer. This research is descriptive qualitative which is described with utterances that are identifiel with social value aspect whether from narration of the paragraph or dialog which reveal the social aspect with social approach. The data in this research is film $G 30 \mathrm{~S} / \mathrm{PKI}$ by Arifin C Noer. From the research, it can be concluded that there are 40 utterances in the film $G 30$ S/PKI Karya Arifin C Noer. It is hoped that the social aspects in the film $G 30 \mathrm{~S} / \mathrm{PKI}$ by Arifin can be used as a guidance in our daily life.

Key Word : interaction, social, film

\footnotetext{
${ }^{1}$ Mahasiswa Program Studi Pendidikan Bahasa dan Sastra Indonesia, Fakultas Keguruan dan Ilmu Pendidikan, Universitas Batanghari Jambi

${ }^{2}$ Dosen Program Studi Pendidikan Bahasa dan Sastra Indonesia, Fakultas Keguruan dan Ilmu Pendidikan, Universitas Batanghari Jambi

${ }^{3}$ Dosen Program Studi Pendidikan Bahasa dan Sastra Indonesia, Fakultas Keguruan dan Ilmu Pendidikan, Universitas Batanghari Jambi
} 


\section{PENDAHULUAN}

Dalam karya sastra terdapat nilainilai kehidupan yang dapat dijadikan sebagai pembelajaran bagi manusia, oleh karena itu peneliti tertarik untuk mengkaji karya sastra. Film adalah media sastra yang digunakan sebagai alat komunikasi yang lebih baik dibandingkan media sastra yang lainnya, tak hanya sebatas itu film memiliki kekuatan dan kemampuan menjangkau banyak segmen sosial sehingga film mampu mempengaruhi khalayaknya, (Sobur, 2003:127). Berdasarkan sumber tersebut maka film mampu menarik perhatian masyarakat karena mampu menunjukkan keeksistensiannya dan tetap bertahan di tengah masyarakat dan terus berkembang.

Interaksi sosial salah satu hal yang penting bagi manusia sehingga dapat berinteraksi secara baik. Interaksi sosial pada saat ini sangat memprihatinkan karena adanya perbedaan kedudukan maupun strata atau tingkatan sosial, rendahnya interaksi sosial juga ditemukan dikalangan pendidikan. Seorang siswa maupun mahasiswa kurang rasa hormat dan interaksi yang baik terhadap guru. Fenomena ini terdapat dalam film $G 30$ $S / P K I$ karya Arifin C Noer yaitu tidak adanya rasa peduli antarsesama manusia sehingga dalam film terjadi pemaksaan terhadap beberapa oknum yang berujung pembunuhan. Salah satu film yang dapat memberikan ajaran bermasyarakat atau bersosial yaitu film G 30 S/PKI Karya Arifin C Noer. Film kontroversi ini merupakan film yang diproduksi pada tahun 1984 dengan durasi kurang lebih 4 jam. Film $G 30$ S/PKI Karya Arifin C Noer merupakan film yang best seller. Arifn $\mathrm{C}$ Noer merupakan sutradara film G $30 \mathrm{~S} / \mathrm{PKI}$. Tokoh ini lahir di Cirebon 10 Maret 1941. Kemampuan dalam sutradara, produser, penulis naskah lakon, dan skenario film merupakan keahliannya.

Karya sastra merupakan hasil imajinasi yang mengandung nilai kehidupan. Karya sastra adalah karya kreatif suatu seni dan bermediumkan bahasa yang tidak absolut" (Susanto, 2016:6). Karya sastra adalah fenomena unik. Ia juga fenomena organik. Di dalamnya penuh serangkaian makna dan fungsi" (Endraswara, 2013:7). Maka dapat simpulkan, bahwa karya sastra tercipta berdasarkan imajinasi, ekspresi, daya khayal pengarang yang tinggi. Karya sastra disusun dengan menggunakan bahasa yang unik sehingga mampu menjadi daya tarik bagi penikmat sastra.

Manfaat karya sastra menurut Rokhmansyah, (2014:8), yaitu: (1) manfaat rekreatif, (2) manfaat didaktif, (3) manfaat estetis, dan (4) manfaat religius. Selain memiliki berbagai manfaat, karya sastra terdapat beberapa jenis di antaranya adalah prosa. Prosa merupakan karya sastra yang penyampaiannya berupa narasi atau cerita. Karya sastra disampaikan melalui suatu penceritaan agar karya sastra mampu menyampaikan nilai kehidupan dengan cara yang mudah untuk dipahami" (Kosasih, 2008: 5). Puisi adalah teks-teks monolog yang isinya tidak pertama-tama merupakan sebuah alur" (Wiyatmi, 2009: 53). Drama adalah kisah kehidupan manusia baik dalam bentuk puisi maupun prosa yang disajikan dalam bentuk gerak dan percakapan atau dialog oleh para pelakon di hadapan pendengan atau penonton" (Supriyadi, 2013:3). Berdasarkan beberapa jenis karya sastra 
yang telah diuraikan di atas, jenis karya sastra yang diteliti yaitu drama yang terdapat jenis drama berdasarkan pementasannya ialah film.

Film merupakan jenis karya sastra yang dapat menyampaikan maksud dan makna cerita secara cepat dan tidak membuang banyak waktu. Film merupakan bidang penerapan semiotik" (Zoest, 1993:109). Drama film merupakan salah satu jenis karya sastra drama yang memiliki perkembangan baik, sehingga mampu bersaing dengan media maupun karya sastra lainnya.

Menurut Effendy (2003:211) mengatakan jenis film adalah film cerita dan film berita. Pendapat yang berbeda yang mengatakan film terdapat beberapa jenis oleh Pratista (2008: 4), jenis film dapat dibedakan menjadi beberapa bagian sebagai berikut: (a) film fiksi, (b) film eksperimental, (c) film dokumenter.

Film merupakan salah jenis karya sastra yang terdiri dari dua unsur pembangun yaitu unsur intrinsik dan ekstrinsik. unsur intrinsik film menurut Hasanuddin, (1996:76) adalah: tokoh, peran, dan karakter. Adapun unsur ekstrinsik film menurut Ratna, (2004:138), adalah: (a) latar belakang kehidupan pengarang, (b) keyakinan, (c) pandangan hidup pengarang, (d) adat istiadat yang berlaku saat itu, (e) situasi politik dan sejarah, dan (f) nilai ekonomi, sosial, agama, dan lain-lainnya.

Dari beberapa unsur-unsur pembangun film di atas, aspek penelitian ini adalah interaksi sosial, Sosial merupakan interaksi dengan sesama manusia untuk menghasilkan hubungan pergaulan hidup dalam bermasyarakat. "Manusia dikatakan makhluk sosial, juga dikerenakan dalam diri manusia ada dorongan untuk berhubungan (interaksi) dengan orang lain" (Setiadi, 2006:63).

Aspek yang akan dikaji dalam film $G 30 \mathrm{~S} / \mathrm{PKI}$ Karya Arifin C Noer yaitu interaksi sosial. interaksi sosial merupakan hal penting dalam bermasyarakat. "Interaksi sosial adalah hubungan-hubungan sosial yang dinamis yang menyangkut hubungan orang perorangan dengan kelompok manusia" (Setiadi, 2006:95). Interaksi sosial dapat berbentuk berjabat tangan, saling menegur, kerja sama dan sebagainya. Hal ini salah satu cara agar nilai sosial dalam kehidupan masyarakat tetap terjaga. "Kerja sama adalah orientasi orang-perorangan terhadap kelompoknya dan kelompok lainnya" (Setiadi, 2006:102), sedangkan "Saling menegur adalah seseorang memberikan tafsiran pada tingkah laku atau perasaanperasaan orang lain dalam bentuk pembicaraan" (Setiadi, 2006:99). Adapun Berjabat tangan adalah meletakkan telapak tangan kepada telapak tangan orang lain dan ditahan beberapa saat, selama rentang waktu yang cukup untuk menyampaikan salam.

Interaksi sosial merupakan suatu hal yang utama dalam kehidupan sosial masyarakat agar terjadi hubungan satu sama lainnya. Menurut Abdulsyani, (2015:156), "Interaksi sosial adalah suatu bentuk proses sosial di mana di dalamnya terdapat aktivitas tertentu yang ditujukan untuk mencapai tujuan bersama". Menurut Soekanto, (2007: 55), "Interaksi sosial adalah syarat utama terjadinya aktivitas-aktivitas sosial".

Berdasarkan fokus penelitian yang diuraikan di atas, maka pertanyaan penelitian ini yaitu: bagaimanakah 
interaksi sosial yang terkandung dalam film G30 S/PKI Karya Arifin C Noer?

Tujuan penelitian adalah untuk menemukan, mengembangkan dan membuktikan pengetahuan (Sugiyono, 2016:143). Berdasarkan pertanyaan penelitian di atas, maka tujuan penelitian ini adalah untuk mendeskripsikan nilainilai interaksi sosial dalam film $G 30$ S/PKI Karya Arifin C Noer.

Setiap penelitian diharapkan memiliki manfaat. Manfaat tersebut bisa bersifat teoretis dan praktis (Sugiyono, 2016:143). Secara teoretis manfaat penelitian ini dapat menambah khazanah ilmu pengetahuan khususnya menginterpretasikan nilai sosial dalam karya sastra. Selanjutnya sebagai perbandingan penelitian yang sejenis, dan dapat memberikan sumbang ide dalam mengembangkan teori pembelajaran apresiasi sastra.

Manfaat praktis, yaitu untuk memecahkan masalah, berguna untuk menjelaskan, memprediksi, dan mengendalikan suatu gejala (Sugiyono, 2016:143). Secara praktis penelitian ini diharapkan dapat bermanfaat bagi beberapa pihak, antara lain:

a. Bagi guru, dapat dijadikan sebagai bahan tambahan pelajaran bahasa dan sastra, khususnya pada kajian struktural.

b. Bagi peneliti berikutnya dapat dijadikan sebagai bahan perbandingan dalam penelitiannya yang berkaitan tentang nilai sosial dalam kajian struktural.

c. Bagi masyarakat dapat menambah pengetahuan tentang ilmu sosial dan struktural khusunya tentang unsur intrinsik dan unsur ekstrinsik.

\section{METODE PENELITIAN}

Jenis penelitian adalah cara yang digunakan oleh peneliti dalam pengumpulan data. Jenis penelitian berperan penting dalam penelitian, karena penelitian terdapat beberapa tujuan pencapaian sehingga penulis membutuhkan jenis penelitian. "Jenis penelitian adalah cara yang digunakan seorang peneliti di dalam usaha memecahkan masalah yang diteliti" (Siswantoro, 2010:55). Jenis penelitian dalam penelitian ini adalah deskriptif kualitatif.

Deskriptif merupakan jenis penelitian yang menggambarkan kejadian. "Deskriptif adalah penelitian yang dimaksud untuk mebuat deskripsi atau gambaran keadaan mengenai situasi-situasi atau kejadian-kejadian" (Suryabrata, 2010:76). Deskriptif merupakan penelitian yang mendeskripsikan atau menggambarkan keadaan maupun situasi objek yang diteliti. Penelitian deskriptif merupakan jenis penelitian kualitatif.

Jenis penelitian kualitatif merupakan penelitian yang lebih menekankan makna dari objek peneltian. "Jenis penelitian kualitatif adalah jenis peneltian yang digunakan untuk meneliti pada kondisi objek yang alamiah, di mana peneliti adalah sebagai instrumen kunci, teknik pengumpulan data dilakukan secara penelitian kualitatif lebih menekankan makna dari pada generalisasi” (Sugiyono, 2016:1). Penelitian sastra merupakan penelitian kualitatif yang digunakan untuk meneliti objek secara alamiah dengan mengutamakan penekanan makna objek penelitian. Maka peneliti akan mampu mendeskripsikan data objek penelitian 
dengan kata-kata terkait fenomena sosial berdasarkan penelitian kualitatif. Berdasarkan jenis deskriptif kualitatif yang telah diuraikan, maka peneliti jadikan sebagai landasan penelitian. Penelitian ini juga disertai analisis agar penelitian lebih mendalam terkait nilai sosial yang terdapat dalam film $G 30$ S/PKI karya Arifin C Noer.

Data dapat dikatakan sebagai anggapan-anggapan. Sesuai yang dikemukakan oleh Hasan (2004:19) bahwa "Data merupakan keteranganketerangan tentang suatu hal, yang berupa sesuatu yang diketahui atau yang dianggap atau anggapan dalam penelitian. Data adalah sumber informasi utama terkait penelitian sesuai dengan fakta yang ada. Maka data dalam penelitian ini adalah dialog film $G 30 \mathrm{~S}$ /PKI karya Arifin C Noer.

Sumber data adalah data yang diperoleh dari sumber yang akan diteliti. "Sumber data terkait dengan subjek penelitian dari mana data diperoleh" (Siswantoro, 2010: 72). Sumber data adalah terkait dimana peneliti mengambil data penelitian tersebut. Sumber data dalam penelitian ini adalah film dokumenter $G 30 \mathrm{~S} / \mathrm{PKI}$ karya Arifin C Noer. Sumber data juga diperoleh dari internet, dan dari berbagai buku perpustakaan diantaranya perpustakaan FKIP, perpustakaan wilayah, dan perpustakaan kota.

Teknik pengumpulan data dapat dikatakan sebagai cara peneliti mengumpulkan suatu data yang digunakan dalam penelitian. "Teknik pengumpulan data merupakan bagian penting dari proses penelitian. Begitu sentral peran pengumpulan data sehingga kualitas penelitian tergantung padanya" (Siswantoro, 2010: 73).

Teknik pengumpulan data dalam penelitian ini menggunakan teknik studi pustaka dan dokumentasi yang difokuskan untuk menganalisis interaksi sosial yang terdapat dalam film $G$ 30/SPKI karya Arifin C Noer.

Pengumpulan data penelitian ini, peneliti mendeskripsikan data berupa langkah-langkah dalam pengumpulan data yang berhubungan interaksi sosial yang terdapat dalam film $G 30 \mathrm{~S} / \mathrm{PKI}$ karya Arifin $\mathrm{C}$ Noer. Teknik pengumpulan data dalam penelitian ini dilakukan dengan langkah-langkah sebagi berikut.

a. Menyimak dengan saksama film $G 30$ S/PKI karya Arifin C Noer.

b. Mentranskripsikan dialog film $G 30$ S/PKI karya Arifin C Noer.

c. Membaca secara teliti serta memahami dialog film $G 30 \mathrm{~S} / \mathrm{PKI}$ karya Arifin C Noer.

d. Peneliti mengulang kembali membaca buku sumber lain tentang interaksi sosial yang berkaitan dengan interaksi sosial

e. Peneliti menandai bagian kata-kata, kalimat, atau paragraf yang berhubungan dengan interaksi sosial dalam film $G 30$ S/PKI karya Arifin C Noer.

f. Peneliti mencatat aspek-aspek yang berkaiatan dengan interaksi sosial dalam film $G 30$ S/PKI karya Arifin C Noer.

g. Kemudian peneliti mengumpulkan data yang berhubungan dengan interaksi sosial dan konflik sosial dalam film $G 30$ S/PKI karya Arifin C Noer.

h. Peneliti menyusun data secara teratur setiap kalimat yang berkaitan dengan 
interaksi sosial dan konflik sosial dalam film $G 30$ S/PKI Karya Arifin C Noer.

i. Setelah itu, peneliti mengelompokkan data sesuai aspek-aspek yang berhubungan dengan interaksi sosial dalam film $G 30$ S/PKI Karya Arifin C Noer.

Teknik analisis data merupakan cara dalam menganalisis data penelitian. Analisis data dilakukan untuk mendapatkan makna terhadap data. Menurut Merriam dalam Tohirin, (2012: 141). "Analisis data merupakan proses memberikan makna terhadap data yang dikumpulkan". Teknik analisis data dengan memaparkan kata-kata, kalimat, paragraf yang berhubungan dengan aspek interaksi sosial dalam film $G 30$ S/PKI Karya Arifin C Noer. Selanjutnya peneliti membuat kesimpulan terhadap masing-masing masalah, dalam penelitian ini dapat berupa kutipankutipan yang terdapat dalam dialog film. Kegiatan analisis data dilakukan dengan langkah-langkah sebagai berikut:

a. Data yang telah dikelompokkan ke dalam data di atas, kemudian ditabulasikan ke dalam tabel tabulasi data.

b. Setelah ditabulasi, langkah selanjutnya, yaitu menginterpretasikan data yang sudah ditabulasikan dengan kerangka teori.

c. Data yang sudah diinterpretasikan, kemudian data tersebut dianalisis sesuai dengan teori yang berkaitan masalah penelitian.

d. Keabsahan data, mengecek data temuan dengan temuan lain sehingga tidak adanya kekontrasan atau kesesuain antara satu dengan lainnya. e. Mendeskripsikan data berdasarkan analisis nilai-nilai interaksi sosial dan konflik sosial.

f. Merumuskan kesimpulan.

\section{HASIL DAN PEMBAHASAN}

Penelitian ini merupakan penelitian deskriptif kualitatif dengan menggunakan analisis struktural. Penelitian terkait nilai sosial merupakan hal yang sering ditemukan dalam kehidupan bersosial. Berdasarkan data yang telah dianalisis terkait interaksi sosial dalam film $G 30$ S/PKI Karya Arifin C Noer, maka ditemukan 40 kutipan nilai sosial yang terdapat dalam film $G 30 \mathrm{~S} / \mathrm{PKI}$ Karya Arifin C Noer. Interaksi sosial merupakan hal yang penting dalam kehidupan sosial. interaksi dapat menghasilkan hubungan antarsesama, komunikasi, kerja sama, tolong menolong dengan baik. Berdasarkan teori yang digunakan peneliti sebagai acuan dalam meneliti interaksi sosial dalam film $G 30 \mathrm{~S} / \mathrm{PKI}$ Karya Arifin C Noer, (Ratna, 2003: 18), mengatakan dalam sosiologi sastra terdapat interaksi sosial, yaitu "Sosiologi sastra terdiri dari kelompok sosial,, kelas sosial, stratifikasi sosial, institusi sosial, sistem sosial, interaksi sosial, konflik sosial, kesadaran sosial, mobilitas sosial". Maka peneliti memadukan teori sosial yang berkaitan dengan interaksi sosial yaitu, Setiadi, (2006: 95), "Interaksi sosial adalah hubunganhubungan sosial yang dinamis yang menyangkut hubungan orang perorangan dengan kelompok manusia”. Berikut salah satu penjabaran interaksi sosial dalam film $G 30$ S/PKI karya Arifin C Noer. 
Pembahasan penelitian ini adalah hasil analisis data yang berupa kutipankutipan yang terdapat dalam dialog film $G \quad 30 \quad S / P K I$ Karya Arifin C Noer. Adapun pembahasan dalam penelitian ini mengenai interaksi sosial yang akan diuraikan satu persatu berikut:

Analisis Interaksi Sosial Saling Menegurdalam Film G 30 S/PKI Karya Arifn C Noer.

1) "Ah si abg mah, oh ya ngomongngomong bagaimana soal bagian kita"." 4 liter". (G 30 S/PKI: 3/19:53)

Dari kutipan (1) di atas terlihat bagaimana masyarakat saling berinteraksi satu sama lain ketika sedang mengantri pembelian bahan bakar. Interaksi sosial tergambar pada kalimat yang menanyakan soal pembagian bahan bakar minyak kepada seseorang yang berada disampingnya, interaksi saling menegur dapat dilihat dari gambar yang sedang berdekatan dan bertegus sapa. Kutipan interaksi sosial ini mengacu adanya hubungan antara sesama dengan saling menegur sehingga terjadi sebuat komunikasi dan hubungan sosial. Kajian memiliki relevansi dengan teori yang digunakan dalam aspek interaksi sosial, yaitu, "Interaksi sosial adalah hubunganhubungan sosial yang dinamis yang menyangkut hubungan orang perorangan dengan kelompok manusia" (Setiadi, 2006: 95).

2) "Kok lewat depan mbo, ujar kepada mbo". "Pintu samping tutup buk". (G 30 S/PKI: 3/21:23)

Dari kutipan (2) di atas terlihat bagaimana seorang majikan yang berinteraksi dengan baik terhadap pembantu rumah tangganya. Interaksi sosial tergambar pada kalimat seorang majikan yang menanyakan kepada si mbo kenapa lewat depan. Kutipan ini merupakan interaksi sosial yang dilakukan dengan saling menegur satu sama lain untuk menjalin hubungan sosial yang baik, hal ini tergambar dari seorang majikan yang sedang duduk di ruang tamu dan si mbo tiba-tiba lewat di sekitarnya. Kajian ini memiliki relevansi dengan teori yang digunakan dalam aspek interaksi sosial yaitu, "Interaksi sosial adalah hubungan-hubungan sosial yang dinamis yang menyangkut hubungan orang perorangan dengan kelompok manusia" (Setiadi, 2006: 95).

3)"Sebelum ketua Aidit berkomentar saya ingin kawan Syam terlebih dahulu menilai punya saya ini". ( $G 30$ S/PKI: 7/35:21)

Dari kutipan (3) di atas terlihat bagaimana Syam sebagai wakil ketua Aidit diminta untuk menilai karya anggotanya sebelum diperiksa oleh Aidit selaku ketua gerakan. Interaksi sosial dalam bentuk saling menegur tergambar dari kalimat yang meminta temannya untuk menilai sebuah karya yang telah dibuatnya agar dapat mengetahui kesalahan maupun sebaliknya. Interaksi sosial dalam kutipan ini terjadi antarindividu yang saling menegur untuk menjalin hubugan sosial yang baik sehingga terjadi suatu interaksi antarsesama. Interaksi sosial dalam kutipan memiliki relevansi dengan teori yang digunakan tentang aspek interaksi sosial yaitu, "Interaksi sosial adalah hubungan-hubungan sosial yang dinamis yang menyangkut hubungan orang perorangan dengan kelompok manusia" (Setiadi, 2006: 95).

4) Ayah adek mau bintang yang banyak, baju adek mau seperti baju ayah". "Yah, Yanti ikut belajar menari boleh kan, 
latihannya sore kok". (G 30 S/PKI: 13/53:57)

Dari kutipan (4) di atas terlihat bagaimana sebuah keluarga yang berinteraksi dengan baik dengan anggota keluarganya. Interaksi tersebut tergambar pada kalimat seorang Yanti yang meminta izin kepada ayah untuk melakukan aktivitas di luar sekolah yang dilaksanakan pada sore hari. Interaksi sosial yang terjadi dalam kutipan ini yaitu antarindividu, hal ini tergambar antara anak dan orangtua yang saling menegur dan meminta izin sehingga terjadi interaksi sosial. Interaksi saling menegur dapat dilihat dari seorang anak yang menjemput ayahnya yaitu Jenderal Nasution di depan rumahnya. Kajian ini memiliki relevansi dengan teori yang digunakan dalam aspek interaksi sosial yaitu, "Interaksi sosial adalah hubunganhubungan sosial yang dinamis yang menyangkut hubungan orang perorangan dengan kelompok manusia" (Setiadi, 2006: 95).

5) "Besok adik mau ikut om pier". "Ikut kemana". $\left(\begin{array}{lll}G & 30 & \mathrm{~S} / \mathrm{PKI} \text { : }\end{array}\right.$ 18/1:12:14)

Dari kutipan (5) di atas terlihat Pierre sebagai paman Ade Irma Suryani Nasution putri dari Jendral Nasution beriteraksi dengan mengajaknya ikut berkunjung dikediaman orangtuanya di Semarang. Dalam kutipan ini interaksi sosial yang terjadi tergambar adanya komunikasi yang baik antarindividu dengan saling menegur untuk menjalin sebuah interaksi sosial, interaksi saling menegur tergambar dari gambar yang menunjukkan Lettu Pierre Tendean yang sedang bermain dihalaman rumah bersama anak Jendral Nasuition dan mengajaknya untuk ikut bersamanya pulang kampung. Interaksi sosial dalam kutipan ini memiliki relevansi dengan teori yang digunakan dalam aspek interaksi sosial, "Interaksi sosial adalah hubungan-hubungan sosial yang dinamis yang menyangkut hubungan orang perorangan dengan kelompok manusia" (Setiadi, 2006: 95).

Analisis Aspek Interaksi Sosial Kerja Sama dalam film $G 30 \mathrm{~S} / \mathrm{PKI}$ karya Arifn C Noer

1) "Untuk sementara pertanyaan saya sama yang dikemukakan kawan sakirman". "Kalau begitu barangkali kawan Sanusi masih punya

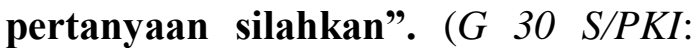
9/43:22)

Dari kutipan (1) di atas terlihat bagaimana Aidit selaku ketua membuka forum tanya jawab dan memberikan kesempatan untuk bertanya. Interaksi sosial yang terjadi dalam kutipan ini yaitu antarindividu.Hal ini tergambar dari kalimat Aidit yang menanyakan kepada Sanusi untuk bertanya apabila ada yang ingin ditanyakan. Interaksi sosial terjadi adanya saling menegur satu sama lain untuk mengemukakan pendapat masing-masing. Interaksi sosial dalam kutipan ini memiliki relevansi dengan teori yang digunakan dalam aspek interaksi sosial yaitu, "Interakasi sosial adalah hubunganhubungan sosial yang dinamis yang menyangkut hubungan orang perorangan dengan kelompok manusia" (Setiadi, 2006: 95).

2) "Hari ini harus kelar ya kalau perlu lembur sampai malam". "Baik pak". (G 30 S/PKI: 10/45:38)

Dari kutipan (2) di atas terlihat bagaimana seorang atasan yang berinteraksi terhadap karyawannya. 
Interaksi tersebut tergambar pada kalimat atasan yang memerintahkan karyawannya untuk menyelesaikan pekerjaannya. Interaksi sosial yang terjadi dalam kutipan ini yaitu antarindividu dengan melakukan kerja sama dalam menyelesaikan suatu pekerjaan, hal ini mencerminkan adanya interaksi sosial yang baik. Interaksi tersebut merupakan interaksi sosial yang baik sesuai dengan teori yang digunakan dalam aspek interaksi sosial yaitu, "Interaksi sosial adalah hubunganhubungan sosial yang dinamis yang menyangkut hubungan orang perorangan dengan kelompok manusia" (Setiadi, 2006: 95).

3) "Pokoknya saya siap dalam pasukan pengawal pemimpin besar revolusi bung Karno...". "Jadi kekuatan militer di Jakarta Utara ada sekitar 60 ribu orang...". (G $30 \mathrm{~S} / \mathrm{PKI}$ : 14/58:28)

Dari kutipan (3) di atas terlihat bagaimana Letnan Latief yang siap bekeraja sama dengan pasukan yang menjadi binahannya untuk membantu sebuah gerakan yang akan dilaksanakan. Interaksi ini terjadi karena adanya kepentingan yang sama. Interaksi sosial dalam kutipan ini tergambar adanya kerja sama dalam dalam sebuah gerakan yang terjadi antarindividu, hal ini tergambar dari ekspresi semangat Latief dalam menawarkan pasukannya untuk bergabung dalam gerakan 30 September. Interaksi sosial ini sesuai dengan teori yang digunakan dalam aspek interaksi sosial yaitu, "Interaksi sosial adalah hubungan-hubungan sosial yang dinamis yang menyangkut hubungan orang perorangan dengan kelompok manusia" (Setiadi, 2006: 95).

\section{4) "Letnan untung yang akan mengetuai gerakan ini silahkan mengoreksi". ( $G 30$ S/PKI: 15/1:02:04)}

Dari kutipan (4) di atas terlihat bagaimana Untung dipersilahkan untuk mengoreksi. interkasi sosial yang terjadi pada kutipan ini ialah saling menghargai dan untuk memberikan koreksi apabila terjadi kesalahan dalam langkah yang telah disusun dalam gerakan yang akan dilakukan. Maka pada kutipan ini terjadi interaksi maupun komunikasi antarindividu dengan saling menegur untuk kebaikan sesama sehingga terbentuk sebuah interaksi sosial yang baik. Hal ini sesuai dengan teori yang digunakan dalam aspek interaksi sosial yaitu, (Interaksi sosial adalah hubunganhubungan sosial yang dinamis yang menyangkut hubungan orang perorangan dengan kelompok manusia" (Setiadi, 2006: 95).

5) "Tidak cuman itu pak saya ingin bekerja membantu petani-petani miskin di gunung kidul hanya dengan kemakmuran paham komunisme bisa di bendung begitu kata bung Hatta saya harus melakukan sesuatu kecuali itu tentu saya akan melanjutkan riset". ( $G$ 30 S/PKI: 21/1:28:17)

Dari kutipan (5) di atas terlihat bagaimana Hanif yang memiliki niat baik untuk bekerja sama dengan kawankawannya untuk membantu masyarakat yang sedang kesusahan di Gunung Kidul. Interaksi sosial dalam kutipan terjadi antara anak dan seorang bapak yang menginginkan anaknya untuk segera menyelesaikan risetnya, dan interaksi kerja sama tergambar dari Hanif yang memiliki tujuan untuk membatu dan bekerja sama dengan mahasiswa lain untuk membantu 
masyarakat di Gunung Kidul yang mengalami kesusahan. Hal ini tergambar interaksi sosial karena adanya kerja sama yang terjadi memiliki relevansi dengan teori yang digunakan dalam aspek interkasi sosial, yaitu: "Interaksi sosial adalah hubungan-hubungan sosial yang dinamis yang menyangkut hubungan orang perorangan dengan kelompok manusia" (Setiadi, 2006: 95).

Analisis Aspek Interaksi Sosial Berjabat Tangan dalam Film G 30 S/PKI Karya Arifn C Noer.

1) "Saya kira mulai malam ini saya harus membiasakan, sekalipun resminya saya ini brigjen tapi dalam gerakan ini saya wakil saudara Untung perkenalkan

\section{SIMPULAN}

Berdasarkan hasil penelitian dapat disimpulkan bahwa terdapat aspek interaksi sosial sebanyak 40 kutipan, yang diperlihatkan melalui adanya saling berkomunikasi, berjabat tangan, dan bekerja sama antarindividu maupun kelompok. Dalam kutipan tersebut interaksi sosial menggabarkan adanya saling membutuhkan satu sama lain dalam kehidupan sosial. pada dasarnya manusia tidak dapat hidup tanpa berinteraksi dan bersosial dengan sesama. Hal ini membuktikan bahwa dalam film $G 30$ S/PKI Karya Arifin C Noer terdapat nilai-nilai sosial kerja sama dapat dijadikan sebagai pembelajarn bersosial. Berdasarkan hasil simpulan interaksi sosial yang terdiri dari saling menegur, kerja sama, dan berjabat tangan dapat disarankan kepada pembaca disarankan agar dapat menjadikan penelitian sebagai acuan kehidupan bersosial sehingga terjalin interaksi sosial yang baik antarsesama. saya Suparjo". "Untung”. ( G 30 S/PKI: 17/1:09:54)

Dari kutipan (1) di atas bagaimana Soeparjo berjabat tangan dan melakukan perkenalan dengan rekannya Untung yang akan melakukan kerja sama bersama. Dalam kutipan ini interaksi sosial yang terjadi tergambar adanya komunikasih yang baik antarindividu.Interaksi sosial dalam kutipan ini sesuai dengan teori yang digunakan, yaitu: "Interaksi sosial adalah hubungan-hubungan sosial yang dinamis yang menyangkut hubungan orang perorangan dengan kelompok manusia" (Setiadi, 2006: 95).

\section{DAFTAR PUSTAKA}

Abdulsyani. (2015). Sosiologi Skematika Teori Terapan. Jakarta: PT Bumi Aksara.

Effendy, Onong Uchjana. (2003). Ilmu Teori dan Filsafat Komunikasi. Bandung: Cipta Aditya Bakti.

Endraswara, Suwardi. (2013). Metode Penelitian Sastra. Yogyakarta: CAPS (Center For Academic Publishing Service).

Hasan, Iqbal. (2004). Analisis Data Penelitian dengan Statistik. Jakarta: PT Bumi Aksara.

Hasanuddin Ws,. (1996). Drama Karya dalam Dua Dimensi. Bandung: Percetakan Angkasa.

Kosasih, E. (2008). Apresiasi Sastra Idonesia. Jakarta: Nobel Edumedia.

Pratista, Himawan. (2008). Memahami Film. Yogyakarta: Homerian Pustaka. 
Ratna, Nyoman Kutha. (2003).

Paradigma Sosiologi Sastra.

Yogyakarta: Pustaka Pelajar.

Ratna, Nyoman Kutha. (2004). Teori, Metode, dan Teknik Penelitian Sastra. Yogyakarta: Pustaka Pelajar.

Rokhmansyah, Alfian. (2014). Studi dan Pengkajian Sastra. Yogyakarta: Remaja Rosdakarya.

Semi, M. Atar. (2012). Metode Penelitian Sastra. Bandung: CV Angkasa.

Setiady, Elly M. (2006). Ilmu Sosial dan Budaya Dasar. Jakarta: Kencana.

Siswantoro. (2010). Metode Penelitian Sastra. Yogyakarta: Pustaka Belajar.

Sobur, Alex. (2006). Semiotika Komunikasi. Bandung: PT Remaja Rosdakarya.
Soekanto, Soejono. (2007). Sosiologi Suatu Pengantar. Jakarta: PT Rajagrafindo Persada.

Sugiyono. (2016). Memahami Penelitian Kualitatif. Bandung: ALFABETA.

Supriyadi. (2013). Teori dan Apresiasi Drama/Teater.

Palembang:

Maheda Utama Jaya.

Suryabrata, Sumadi. (2010). Metodologi Penelitian. Jakarta: PT Rajagrafindo Persada.

Susanto, Dwi. (2016). Pengantar Kajian Sastra. Yogyakarta: CAPS.

Tohirin. (2012). Metode Penelitian Kualitatif Dalam Pendidikan dan Bimbingan Konseling. Jakarta: PT Rajgrafindo Persada.

Van Zoest, Aart. (1993). Semiotika.

Wiyatmi. (2009). Pengantar Kajian Sastra. Yogyakarta: Pustaka Book Publishing. 